\title{
CAROTENOIDS AND SEXUAL DICHROMATISM IN NORTH AMERICAN PASSERINE BIRDS
}

\author{
David A. Gray* \\ Department of Biology, 167 Castetter Hall, University of New Mexico, Albuquerque, \\ New Mexico 87131
}

Submitted February 3, 1995; Revised November 9, 1995; Accepted November 17, 1995

\begin{abstract}
Sexual dichromatism and the extent of male carotenoid-derived plumage coloration in breeding season North American passerine birds was analyzed by phylogenetic statistical methods. Passerines as a whole and five passerine subclades were analyzed by both independent contrasts and simulation methods. In passerines as a whole, carotenoids and sexual dichromatism are positively correlated irrespective of analysis method. In three of the subclades, the correlations are significant by a clear majority of analysis methods. Neither melanin nor structurally derived colors show similar significant increases with dichromatism. Carotenoids are obtained by animals solely through the diet, whereas both melanins and structurally derived colors can be synthesized. The relationship between sexual dichromatism and the use of carotenoids in plumage suggests that sexual selection may have promoted the expression of a conditiondependent honest indicator of phenotypic quality.
\end{abstract}

In birds with nuptial display feathers, carotenoids undoubtedly play a positive rôle which is possibly a true sexual function. (Goodwin 1952, p. 267)

The function(s) of sexual dichromatism and bright plumage coloration has been the focus of much research and debate (Darwin 1871; Sibley 1957; Selander 1972; Baker and Parker 1979; Hamilton and Zuk 1982). Largely missing from this debate has been a consideration of the biochemical basis of plumage coloration. The majority of avian plumage coloration is produced by one, or a combination of several, of four major types of color determinants. Three of these four are pigments, namely carotenoids, melanins, and porphyrins; the fourth is due to the physical scattering of light by microscopic airspaces within the keratin of the feather itself and by reflection from the feather barbules-so-called structural coloration (Fox 1976; Brush 1978). In general, white, blue, and iridescent plumage coloration is produced structurally (Fox 1976; Brush 1978); bright red, orange, and yellow plumage coloration is due to carotenoid pigments (Fox and Vevers 1960; Fox 1976; Brush 1978; Hudon and Brush 1992); brown, black, gray, buff, and dull brownish red, dull orange, and dull yellowish plumage coloration is due to melanin pigments (Fox 1976; Brush 1978). Porphyrins produce colors ranging from brown to blue, green, and red. Although widely distributed among avian taxa, porphyrins tend to be restricted to feathers or parts of feathers not exposed

*E-mail: nodster@carina.unm.edu. 
to direct sunlight (Brush 1978), for example, feather shafts of young pigeons (Fox 1976). Exceptions are owls (Strigidae), bustards (Otididae), and turacos (Musophagidae). As the present analysis is restricted to passerines, and porphyrins tend to be restricted to unexposed feather areas, porphyrins are not considered further here.

Carotenoids are synthesized only in plants, algae, and some bacteria and fungi. Although many animals can modify the structure of ingested carotenoids, no animals have been shown to synthesize them (Fox and Vevers 1960; Fox 1976, 1979; Brush 1978); therefore, all carotenoids found within animals must have been obtained through the diet. Because of this, a condition-dependent signaling role for carotenoids has been suggested by several authors (Kodric-Brown and Brown 1984; Andersson 1986; Hill 1990; Zuk 1992). Melanins are produced in animals by the catabolism of the amino acids tyrosine, tryptophan, and phenylalanine (Fox 1976; Brush 1978). Anabolic and catabolic pathways can interconvert proteins and these amino acids (Fox 1976). For this reason, melanins are less likely than carotenoids to be limited, honest indicators of phenotypic quality. Structural colors are produced by properties of the feather, as previously noted. Feather structure abnormalities are infrequent and usually lethal in wild birds (Harrison 1985). For this reason, structural colors, in and of themselves, are less likely than carotenoid-derived colors to honestly indicate phenotypic quality, except perhaps extreme (i.e., usually fatal) nutritional, disease, or genetic stress.

The basis of avian plumage coloration suggests that carotenoid-derived colors, in and of themselves, have the potential to honestly reflect phenotypic quality, whereas melanin and structurally derived coloration may do so if coupled with an additional honesty-enforcing mechanism. This is not to argue that traits that are synthesized endogenously are necessarily poor indicators of phenotypic quality. What is being argued, however, is that carotenoid pigments by their nature have greater potential to be honest indicators of phenotypic quality than do either melanins or structural colors in the absence of additional honesty-enforcing mechanisms. Clearly many synthesized traits do reflect phenotypic quality, for example, the tail of the male peafowl, Pavo cristatus (Petrie 1994), the size of the comb of red jungle fowl, Gallus gallus (Ligon et al. 1990; Zuk et al. 1990a), and the size and symmetry of several feather ornaments (Møller and Pomiankowski 1993). Synthesized traits that do honestly reflect phenotypic quality, however, most likely will require an additional mechanism to enforce honesty, for example, strong opposing natural selection, that is, handicap traits (Zahavi 1975, 1991), or testosterone-mediated expression (Folstad and Karter 1992). For example, the badge of the male house sparrow, Passer domesticus, is produced by melanin. It acts as a signal of social dominance and status (Møller 1987a). However, so far as anyone knows, the honesty of the badge as a signal is unrelated to the fact that it is produced by melanin. Instead, honesty is maintained through social interaction (Møller 1987b). Testosterone-mediated trait expression seems an unlikely honesty-enforcing mechanism for avian plumage, as male-type plumage in most species of birds develops from the absence of estrogen rather than the presence of testosterone (see Owens and Short 1995). 
If sexual selection, either by male-male competition or by female choice, operates on the basis of condition-dependent honest indicators of quality (Zahavi 1975, 1991; Andersson 1982, 1986; Kodric-Brown and Brown 1984; Grafen 1990), then carotenoid, but not necessarily melanin or structural, coloration would be expected to increase in lineages with increased sexual selection. To test this hypothesis, I looked for interspecific correlations between sexual dichromatism and the proportion of carotenoid, melanin, and structurally derived plumage coloration. Specifically, the hypothesis predicts positive correlations between carotenoid-derived plumage coloration and sexual dichromatism.

This argument assumes that sexual dichromatism reflects the accumulated effects of sexual selection rather than other selective pressures (Darwin 1871; Selander 1972; Baker and Parker 1979; Møller and Birkhead 1994). It is also assumed that the biochemical origin of plumage colors can reliably be inferred from the color itself without requiring direct biochemical evidence for all species. This assumption may seem tenuous at best; however, Hudon and Brush (1992, p. 319) state, "Carotenoids produce the majority of bright yellow, orange, and red hues found in birds . . . plumage color is a good indicator of the kinds of carotenoids deposited." That is, not only can the presence of carotenoids reliably be inferred from plumage color, but the specific types of carotenoids may also be inferred. Known exceptions include hummingbird (Trochilidae) gorgets, which are produced structurally, parrot (Psittaciiformes) red and yellow feathers, which have an unknown, but probably noncarotenoid, color origin (Hudon and Brush 1992), and the green and red pigments of turacos (Musophagidae), which derive from the porphyrins turacoverdin and turacin (Fox 1976).

An important difference between this study and previous studies of the evolutionary significance of avian coloration is the analysis of dichromatism and the underlying biochemical nature of coloration. This approach has at least two major advantages. First the concepts of "conspicuousness" and "brightness" are avoided. This is a significant improvement over previous analyses because conspicuousness and brightness are subjective and dependent on ecologically relevant environmental conditions. In addition, as humans almost universally perceive carotenoid coloration as bright, correlating carotenoid coloration with "brightness" would be tautological. Second, the results are more likely to be independent of differences between human and avian sensory systems, which are greater than previously appreciated (Bennett et al. 1994).

\section{METHODS}

\section{Data Collection}

North American passerines for which information was available in a standard field guide (National Geographic Society 1987) and in a technical bird-banding guide (Pyle et al. 1987) and for which phylogenetic information was available in Sibley and Ahlquist (1990) were used. Each of 12 plumage regions was scored for sexual dichromatism (i.e., dichromatic or not dichromatic) and probable color origin (i.e., carotenoid, melanin, structural, or a combination of these). Green 
coloration can be produced in several ways (Fox and Vevers 1960; Brush 1978), and scoring its color origin is more ambiguous than is scoring red or black. To be conservative when assigning a carotenoid origin to coloration, noniridescent bright green was scored as carotenoid/structural, that is, yellow plus blue (e.g., green jay, Cyanocorax yncas; painted bunting, Passerina ciris), whereas iridescent green (e.g., European starling, Sturnus vulgaris; violet-green swallow, Tachycineta thalassina), dull green (e.g., green-tailed towhee, Pipilo chlorurus), and olive (e.g., Wilson's warbler, Wilsonia pusilla) were scored as melanin/structural. (Note that because of a lack of phylogenetic information, not all of the above examples were used in the analysis.) The plumage regions scored were as follows: crown, eye stripe, auricular, throat, nape, mantle, wing, breast, belly, rump, undertail coverts, and tail. The dichromatism, carotenoid, melanin, and structural scores for the 12 regions were individually summed, averaged within genera, and converted to proportions. The arcsines of the square roots of the proportions were used in analysis. The untransformed generic averages and species values are given in table 1.

\section{Analysis}

Because phylogenetic history will usually cause more closely related species to be more similar than are more distantly related species, species (or even higher taxonomic units) cannot be considered statistically independent data points (Harvey and Pagel 1991; Miles and Dunham 1993). Because of the effects of phylogenetic history, I used a current hypothesis about the phylogeny of passerines (Sibley and Ahlquist 1990) and phylogenetically appropriate analyses. One approach is to compute phylogenetically independent contrasts (Felsenstein 1985, 1988; Harvey and Pagel 1991; Garland et al. 1992). The other is to use simulations to create null distributions for hypothesis testing (Martins and Garland 1991; Garland et al. 1993). These are described separately below.

I used the PDTREE module of the Phenotypic Diversity Analysis Program (Garland et al. 1993; T. Garland, Jr., personal communication) to compute independent contrasts and check that they were adequately standardized (Garland et al. 1992). Contrasts are standardized by dividing them by the square root of the sum of their branch lengths. If a plot of the absolute values of the contrasts versus their standard deviations shows any linear or nonlinear trends, then the contrasts do not receive equal weight in subsequent correlation or regression analyses. When this was the case, the branch lengths were transformed (see Garland et al. 1992). Once contrasts were adequately standardized, they were used for correlation through the origin (Harvey and Pagel 1991; Garland et al. 1992). The correlation was tested for significance against normal statistical tables (e.g., Rohlf and Sokal 1981). Polytomies can reduce the degrees of freedom available for statistical testing (Purvis and Garland 1993). The phylogeny I used contains four polytomies, two in the Tyrannidae and two in the Corvoidea. Because of this, I report statistical significance for the range of minimum to maximum degrees of freedom.

The simulation analyses consist of comparing the observed Pearson correlation across tip values with 1,000 correlations across tip values of data simulated under 
TABLE 1

The Sample of North American Passerines Used in This Study

\begin{tabular}{|c|c|c|c|c|}
\hline \multirow[b]{2}{*}{ ANALYSIS Group } & \multicolumn{4}{|c|}{ Generic Averages and Species Values } \\
\hline & Dichromatism & Carotenoid & Melanin & Structural \\
\hline \multicolumn{5}{|l|}{ Corvoidea: } \\
\hline Aphelocoma (2) & 0 & 0 & 5.5 & 6.5 \\
\hline A. coerulescens & 0 & 0 & 6 & 6 \\
\hline A. ultramarina & 0 & 0 & 5 & 7 \\
\hline Corvus (5) & 0 & 0 & 12 & 0 \\
\hline C. brachyrhynchos & 0 & 0 & 12 & 0 \\
\hline C. caurinus & 0 & 0 & 12 & 0 \\
\hline C. corax & 0 & 0 & 12 & 0 \\
\hline C. cryptoleucus & 0 & 0 & 12 & 0 \\
\hline C. ossifragus & 0 & 0 & 12 & 0 \\
\hline Cyanocitta (2) & 0 & 0 & 4 & 8 \\
\hline C. cristata & 0 & 0 & 3 & 9 \\
\hline C. stelleri & 0 & 0 & 5 & 7 \\
\hline Cyanocorax (1) & 0 & 3.5 & 2 & 6.5 \\
\hline C. yncas & 0 & 3.5 & 2 & 6.5 \\
\hline Gymnorhinus (1) & 0 & 0 & 1 & 11 \\
\hline G. cyanocephalus & 0 & 0 & 1 & 11 \\
\hline Lanius (2) & 0 & 0 & 7.5 & 4.5 \\
\hline L. excubitor & 0 & 0 & 7.5 & 4.5 \\
\hline L. ludovicianus & 0 & 0 & 7.5 & 4.5 \\
\hline Nucifraga (1) & 0 & 0 & 10 & 2 \\
\hline N. columbiana & 0 & 0 & 10 & 2 \\
\hline Perisoreus (1) & 0 & 0 & 7 & 5 \\
\hline P. canadensis & 0 & 0 & 7 & 5 \\
\hline Pica (2) & 0 & 0 & 8 & 4 \\
\hline P. nuttalli & 0 & 0 & 8 & 4 \\
\hline P. pica & 0 & 0 & 8 & 4 \\
\hline Vireo (14) & .29 & .68 & 7.18 & 4.14 \\
\hline$V$. altiloquus & 0 & 0 & 8.5 & 3.5 \\
\hline V. atricapillus & 4 & .5 & 5.5 & 6 \\
\hline$V$. bellii bellii & 0 & 0 & 8 & 4 \\
\hline$V$. bellii (western forms) & 0 & 0 & 8 & 4 \\
\hline V. flavifrons & 0 & 3 & 5 & 4 \\
\hline$V \cdot$ gilvus & 0 & 0 & 7 & 5 \\
\hline V. griseus & 0 & 2 & 8 & 2 \\
\hline$V$. huttoni & 0 & 0 & 7.5 & 4.5 \\
\hline V. olivaceus olivaceus & 0 & 0 & 7 & 5 \\
\hline V. olivaceus flavoviridis & 0 & 2 & 5 & 5 \\
\hline V. philadelphicus & 0 & 1 & 7 & 4 \\
\hline$V$. solitarius (eastern forms) & 0 & 1 & 6 & 5 \\
\hline V. solitarius plumbeus & 0 & 0 & 9 & 3 \\
\hline V. vicinior & 0 & 0 & 9 & 3 \\
\hline \multicolumn{5}{|l|}{ Muscicapoidea: } \\
\hline Bombycilla (2) & 2.5 & 1.25 & 10.25 & .5 \\
\hline B. cedrorum & 3 & 1.75 & 9.25 & 1 \\
\hline B. garrulus & 2 & .75 & 11.25 & 0 \\
\hline Catharus (4) & 0 & 0 & 9.25 & 2.75 \\
\hline C. fuscescens & 0 & 0 & 10 & 2 \\
\hline C. guttatus & 0 & 0 & 9 & 3 \\
\hline C. minimus & 0 & 0 & 9 & 3 \\
\hline C. ustulatus & 0 & 0 & 9 & 3 \\
\hline Cinclus (1) & 0 & 0 & 12 & 0 \\
\hline C. mexicanus & 0 & 0 & 12 & 0 \\
\hline
\end{tabular}


TABLE 1 (Continued)

\begin{tabular}{|c|c|c|c|c|}
\hline \multirow[b]{2}{*}{ ANALYSIS GROUP } & \multicolumn{4}{|c|}{ Generic Averages and Species Values } \\
\hline & Dichromatism & Carotenoid & Melanin & Structural \\
\hline Dumetella (1) & 0 & 0 & 12 & 0 \\
\hline D. carolinensis & 0 & 0 & 12 & 0 \\
\hline Hylocichla (1) & 0 & 0 & 9 & 3 \\
\hline H. mustelina & 0 & 0 & 9 & 3 \\
\hline Mimus (1) & 0 & 0 & 10 & 2 \\
\hline M. polyglottos & 0 & 0 & 10 & 2 \\
\hline Myadestes (1) & 0 & 0 & 12 & 0 \\
\hline M. townsendi & 0 & 0 & 12 & 0 \\
\hline Oreoscoptes (1) & 0 & 0 & 10 & 2 \\
\hline O. montanus & 0 & 0 & 10 & 2 \\
\hline Phainopepla (1) & 12 & 0 & 12 & 0 \\
\hline$P$. nitens & 12 & 0 & 12 & 0 \\
\hline Sialia $(3)$ & 11.33 & 0 & 1.33 & 10.67 \\
\hline S. currucoides & 12 & 0 & 0 & 12 \\
\hline S. mexicana & 11 & 0 & 1.5 & 10.5 \\
\hline S. sialis & 11 & 0 & 2.5 & 9.5 \\
\hline Sturnus (1) & 1 & 0 & 6 & 6 \\
\hline S. vulgaris & 1 & 0 & 6 & 6 \\
\hline Toxostoma (7) & 0 & 0 & 10.5 & 1.5 \\
\hline T. bendirei & 0 & 0 & 10.5 & 1.5 \\
\hline T. crissale & 0 & 0 & 11 & 1 \\
\hline T. curvirostre & 0 & 0 & 10 & 2 \\
\hline T. lecontei & 0 & 0 & 11 & 1 \\
\hline$T$. longirostre & 0 & 0 & 10 & 2 \\
\hline T. redivivum & 0 & 0 & 11 & 1 \\
\hline T. rufum & 0 & 0 & 10 & 2 \\
\hline Turdus (1) & 5 & 0 & 10.5 & 1.5 \\
\hline T. migratorius & 5 & 0 & 10.5 & 1.5 \\
\hline \multicolumn{5}{|l|}{ Passeroidea: } \\
\hline Agelaius (2) & 12 & .5 & 11.5 & 0 \\
\hline A. phoeniceus & 12 & .5 & 11.5 & 0 \\
\hline A. tricolor & 12 & .5 & 11.5 & 0 \\
\hline Cardinalis (2) & 10 & 6.13 & 5.38 & .5 \\
\hline C. cardinalis & 12 & 8 & 4 & 0 \\
\hline C. sinuatus & 8 & 4.25 & 6.75 & 1 \\
\hline Carduelis (7) & 6.14 & 3.46 & 6.82 & 1.71 \\
\hline C. flammea & 2 & 2 & 7.5 & 2.5 \\
\hline C. hornemanni & 2 & 2 & 7 & 3 \\
\hline C. lawrencei & 8 & 3.5 & 7.5 & 1 \\
\hline C. pinus & 2 & .75 & 9.25 & 2 \\
\hline C. psaltria (black-backed) & 10 & 4 & 8 & 0 \\
\hline C. psaltria (green-backed) & 9 & 5.5 & 5 & 1.5 \\
\hline C. tristis & 10 & 6.5 & 3.5 & 2 \\
\hline Carpodacus (3) & 5.67 & 4.33 & 6.17 & 1.5 \\
\hline C. cassinii & 4 & 2.5 & 7.5 & 2 \\
\hline C. mexicanus & 5 & 4.5 & 6.5 & 1 \\
\hline C. purpureus & 8 & 6 & 4.5 & 1.5 \\
\hline Chondestes (1) & 0 & 0 & 7.25 & 4.75 \\
\hline C. grammacus & 0 & 0 & 7.25 & 4.75 \\
\hline Dendroica (23) & 4.39 & 2.47 & 6.41 & 3.12 \\
\hline D. caerulescens & 12 & 0 & 2 & 10 \\
\hline D. castanea & 8 & 0 & 12 & 0 \\
\hline D. cerulea & 10 & 0 & 0 & 12 \\
\hline D. chrysoparia & 4 & 2 & 7.5 & 2.5 \\
\hline
\end{tabular}


TABLE 1 (Continued)

\begin{tabular}{|c|c|c|c|c|}
\hline \multirow[b]{2}{*}{ ANALYSIS GROUP } & \multicolumn{4}{|c|}{ Generic Averages and Species Values } \\
\hline & Dichromatism & Carotenoid & Melanin & Structural \\
\hline D. coronata auduboni & 6 & 3 & 7 & 2 \\
\hline D. coronata coronata & 5 & 1.5 & 6.5 & 4 \\
\hline D. discolor & 3 & 3.5 & 6 & 2.5 \\
\hline D. dominica & 3 & 1.5 & 7 & 3.5 \\
\hline D. fusca & 7 & 4 & 7 & 1 \\
\hline D. graciae & 2 & 3 & 7 & 2 \\
\hline D. kirtlandii & 3 & 2 & 9 & 1 \\
\hline D. magnolia & 5 & 3.5 & 6 & 2.5 \\
\hline D. nigrescens & 4 & .25 & 8 & 3.75 \\
\hline D. occidentalis & 1 & 2.5 & 6.5 & 3 \\
\hline D. palmarum hypochrysea & 0 & 4.5 & 7.5 & 0 \\
\hline D. palmarum palmarum & 0 & 3 & 7.5 & 1.5 \\
\hline D. pensylvanica & 4 & 1 & 6.5 & 4.5 \\
\hline D. petechia & 7 & 11 & 1 & 0 \\
\hline D. pinus & 4 & 2 & 5.5 & 4.5 \\
\hline D. striata & 5 & 0 & 9 & 3 \\
\hline D. tigrina & 5 & 4.5 & 6 & 1.5 \\
\hline D. townsendi & 1 & 2.5 & 7 & 2.5 \\
\hline D. virens & 2 & 1.5 & 6 & 4.5 \\
\hline Dolichonyx (1) & 12 & 0 & 10.5 & 1.5 \\
\hline D. oryzivorus & 12 & 0 & 10.5 & 1.5 \\
\hline Eremophila (1) & 4 & 3 & 7.5 & 1.5 \\
\hline E. alpestris & 4 & 3 & 7.5 & 1.5 \\
\hline Helmitheros (1) & 0 & 0 & 11 & 1 \\
\hline$H$. vermivorus & 0 & 0 & 11 & 1 \\
\hline Icteria (1) & 1 & 2 & 7 & 3 \\
\hline I. virens & 1 & 2 & 7 & 3 \\
\hline Icterus (7) & 10.29 & 4.68 & 7.14 & .18 \\
\hline I. cucullatus & 12 & 7 & 5 & 0 \\
\hline I. galbula galbula & 12 & 3.75 & 7.5 & .75 \\
\hline I. galbula bullockii & 12 & 6 & 5.5 & .5 \\
\hline I. graduacauda & 12 & 4.75 & 7.25 & 0 \\
\hline I. gularis & 0 & 7.25 & 4.75 & 0 \\
\hline I. parisorum & 12 & 4 & 8 & 0 \\
\hline I. spurius & 12 & 0 & 12 & 0 \\
\hline Junco (2) & 4.8 & .13 & 10.25 & 1.63 \\
\hline J. hyemalis & 5.6 & .25 & 9.5 & 2.25 \\
\hline J. phaeonotus & 4 & 0 & 11 & 1 \\
\hline Leucosticte (1) & 4 & 2 & 10 & 0 \\
\hline L. arctoa & 4 & 2 & 10 & 0 \\
\hline Melospiza (3) & 0 & 0 & 10 & 2 \\
\hline M. georgiana & 0 & 0 & 10.5 & 1.5 \\
\hline M. lincolnii & 0 & 0 & 10 & 2 \\
\hline M. melodia & 0 & 0 & 9.5 & 2.5 \\
\hline Myioborus (1) & 0 & 1.5 & 9.5 & 1 \\
\hline M. pictus & 0 & 1.5 & 9.5 & 1 \\
\hline Passer (2) & 3 & 0 & 11.5 & .5 \\
\hline P. domesticus & 6 & 0 & 11.5 & .5 \\
\hline P. montanus & 0 & 0 & 11.5 & .5 \\
\hline Pheucticus (2) & 10 & 2.35 & 6.95 & 2.7 \\
\hline P. ludovicianus & 10 & 1.2 & 7.4 & 3.4 \\
\hline P. melanocephalus & 10 & 3.5 & 6.5 & 2 \\
\hline Pinicola (1) & 9 & 8.5 & 3.5 & 0 \\
\hline$P$. enucleator & 9 & 8.5 & 3.5 & 0 \\
\hline
\end{tabular}


TABLE 1 (Continued)

\begin{tabular}{|c|c|c|c|c|}
\hline \multirow[b]{2}{*}{ ANALYSIS GROUP } & \multicolumn{4}{|c|}{ Generic Averages and Species Values } \\
\hline & Dichromatism & Carotenoid & Melanin & Structural \\
\hline Piranga (4) & 12 & 9.81 & 2.19 & 0 \\
\hline P. flava & 12 & 8.5 & 3.5 & 0 \\
\hline P. ludoviciana & 12 & 9.25 & 2.75 & 0 \\
\hline P. olivacea & 12 & 10 & 2 & 0 \\
\hline P. rubra & 12 & 11.5 & .5 & 0 \\
\hline Pooecetes (1) & 0 & 0 & 9 & 3 \\
\hline P. gramineus & 0 & 0 & 9 & 3 \\
\hline Protonotaria (1) & 7 & 7 & 1 & 4 \\
\hline P. citrea & 7 & 7 & 1 & 4 \\
\hline Spizella (6) & .33 & 0 & 10.5 & 1.5 \\
\hline S. arborea & 0 & 0 & 12 & 0 \\
\hline S. atrogularis & 2 & 0 & 11 & 1 \\
\hline S. breweri & 0 & 0 & 9 & 3 \\
\hline S. pallida & 0 & 0 & 9 & 3 \\
\hline S. passerina & 0 & 0 & 10 & 2 \\
\hline S. pusilla & 0 & 0 & 12 & 0 \\
\hline Vermivora (10) & 3.6 & 2.6 & 6.8 & 2.6 \\
\hline V. bachmanii & 4 & 3.5 & 7.5 & 1 \\
\hline$V$. celata celata & 1 & 1.5 & 7.5 & 3 \\
\hline V. celata lutescens & 7 & 5.5 & 6 & .5 \\
\hline V. chrysoptera & 4 & 1 & 6.5 & 4.5 \\
\hline$V$. crissalis & 0 & 0 & 12 & 0 \\
\hline V. luciae & 2 & 2 & 6 & 4 \\
\hline$V$. peregrina & 5 & 0 & 5.5 & 6.5 \\
\hline$V$. pinus & 5 & 6 & 2 & 4 \\
\hline V. ruficapilla & 6 & 4 & 7.5 & .5 \\
\hline V. virginiae & 2 & 2.5 & 7.5 & 2 \\
\hline \multicolumn{5}{|l|}{ Sylvioidea: } \\
\hline Auriparus (1) & 5 & 4 & 8 & 0 \\
\hline A. flaviceps & 5 & 4 & 8 & 0 \\
\hline Campylorhynchus (1) & 0 & 0 & 7 & 5 \\
\hline C. brunneicapillus & 0 & 0 & 7 & 5 \\
\hline Certhia (1) & 0 & 0 & 7 & 5 \\
\hline C. americana & 0 & 0 & 7 & 5 \\
\hline Chamaea (1) & 0 & 0 & 12 & 0 \\
\hline C. fasciata & 0 & 0 & 12 & 0 \\
\hline Hirundo (3) & 4 & 0 & 5 & 7 \\
\hline H. fulva & 0 & 0 & 6 & 6 \\
\hline H. pyrrhonota & 0 & 0 & 5 & 7 \\
\hline H. rustica & 12 & 0 & 4 & 8 \\
\hline Parus (9) & 0 & 0 & 10.22 & 1.78 \\
\hline$P$. atricapillus & 0 & 0 & 10 & 2 \\
\hline P. bicolor & 0 & 0 & 8.5 & 3.5 \\
\hline P. carolinensis & 0 & 0 & 10 & 2 \\
\hline P. gambeli & 0 & 0 & 10 & 2 \\
\hline P. hudsonicus & 0 & 0 & 10 & 2 \\
\hline$P$. inornatus & 0 & 0 & 12 & 0 \\
\hline P. rufescens & 0 & 0 & 9.5 & 2.5 \\
\hline P. sclateri & 0 & 0 & 11 & 1 \\
\hline P. wollweberi & 0 & 0 & 11 & 1 \\
\hline Polioptila (3) & 3.67 & 0 & 5.67 & 6.33 \\
\hline P. caerulea & 3 & 0 & .5 & 11.5 \\
\hline P. melanura & 3 & 0 & 9 & 3 \\
\hline$P$. nigriceps & 5 & 0 & 7.5 & 4.5 \\
\hline
\end{tabular}


TABLE 1 (Continued)

\begin{tabular}{|c|c|c|c|c|}
\hline \multirow[b]{2}{*}{ ANALYsis Group } & \multicolumn{4}{|c|}{ Generic Averages and Species Values } \\
\hline & Dichromatism & Carotenoid & Melanin & Structural \\
\hline Progne (1) & 4 & 0 & 7 & 5 \\
\hline P. subis & 4 & 0 & 7 & 5 \\
\hline Psaltriparus (1) & 1 & 0 & 11 & 1 \\
\hline$P$. minimus & 1 & 0 & 11 & 1 \\
\hline Regulus (2) & 1 & .5 & 9 & 2.5 \\
\hline$R$. calendula & 1 & .5 & 11.5 & 0 \\
\hline R. satrapa & 1 & .5 & 6.5 & 5 \\
\hline Riparia (1) & 0 & 0 & 9 & 3 \\
\hline R. riparia & 0 & 0 & 9 & 3 \\
\hline Sitta $(4)$ & 1.5 & 1.13 & 7.88 & 3 \\
\hline S. canadensis & 4 & 3.5 & 7 & 1.5 \\
\hline S. carolinensis & 2 & 1 & 6.5 & 4.5 \\
\hline S. pusilla & 0 & 0 & 9 & 3 \\
\hline S. pygmaea & 0 & 0 & 9 & 3 \\
\hline Stelgidopteryx (1) & 0 & 0 & 8 & 4 \\
\hline S. serripennis & 0 & 0 & 8 & 4 \\
\hline Thryomanes (1) & 0 & 0 & 8 & 4 \\
\hline T. bewickii & 0 & 0 & 8 & 4 \\
\hline Thryothorus (1) & 0 & 0 & 9 & 3 \\
\hline T. ludovicianus & 0 & 0 & 9 & 3 \\
\hline Troglodytes (2) & 0 & 0 & 12 & 0 \\
\hline T. aedon & 0 & 0 & 12 & 0 \\
\hline T. troglodytes & 0 & 0 & 12 & 0 \\
\hline \multicolumn{5}{|l|}{ Tyrannidae: } \\
\hline Camptostoma & 0 & 0 & 10 & 2 \\
\hline C. imberbe & 0 & 0 & 10 & 2 \\
\hline Contopus (4) & 0 & 0 & 10 & 2 \\
\hline C. borealis & 0 & 0 & 9.5 & 2.5 \\
\hline C. pertinax & 0 & 0 & 11 & 1 \\
\hline C. sordidulus & 0 & 0 & 9.5 & 2.5 \\
\hline C. virens & 0 & 0 & 10 & 2 \\
\hline Empidonax (10) & 0 & .4 & 9.1 & 2.5 \\
\hline E. alnorum & 0 & .5 & 8.5 & 3 \\
\hline E. difficilis & 0 & .5 & 9.5 & 2 \\
\hline E. flaviventris & 0 & .5 & 8.5 & 3 \\
\hline E. fulvifrons & 0 & 0 & 10 & 2 \\
\hline E. hammondii & 0 & .5 & 10.5 & 1 \\
\hline E. minimus & 0 & .5 & 9.5 & 2 \\
\hline E. oberholseri & 0 & .5 & 9.5 & 2 \\
\hline E. traillii & 0 & .5 & 9.5 & 2 \\
\hline E. virescens & 0 & .5 & 6.5 & 5 \\
\hline E. wrightii & 0 & 0 & 9 & 3 \\
\hline Myiarchus (4) & 0 & 1.25 & 10 & .75 \\
\hline M. cinerascens & 0 & 1 & 10 & 1 \\
\hline M. crinitus & 0 & 2 & 10 & 0 \\
\hline M. tuberculifer & 0 & 1 & 10 & 1 \\
\hline M. tyrannulus & 0 & 1 & 10 & 1 \\
\hline Myiodynastes (1) & 0 & 1.5 & 7.25 & 3.25 \\
\hline$M$. luteiventris & 0 & 1.5 & 7.25 & 3.25 \\
\hline Pachyramphus (1) & 10 & 1 & 11 & 0 \\
\hline P. aglaiae & 10 & 1 & 11 & 0 \\
\hline Pitangus (1) & 0 & 3.5 & 6.5 & 2 \\
\hline P. sulphuratus & 0 & 3.5 & 6.5 & 2 \\
\hline Pyrocephalus (1) & 12 & 6 & 6 & 0 \\
\hline P. rubinus & 12 & 6 & 6 & 0 \\
\hline
\end{tabular}


TABLE 1 (Continued)

\begin{tabular}{|c|c|c|c|c|}
\hline \multirow[b]{2}{*}{ ANALYSIS GROUP } & \multicolumn{4}{|c|}{ Generic Averages and Species Values } \\
\hline & Dichromatism & Carotenoid & Melanin & Structural \\
\hline Sayornis (3) & 0 & 0 & 10.33 & 1.67 \\
\hline S. nigricans & 0 & 0 & 10 & 2 \\
\hline S. phoebe & 0 & 0 & 9 & 3 \\
\hline S. saya & 0 & 0 & 12 & 0 \\
\hline Tyrannus (8) & .38 & 1.81 & 8.25 & 1.94 \\
\hline T. couchii & 0 & 2.5 & 7.5 & 2 \\
\hline T. crassirostris & 0 & .5 & 8.5 & 3 \\
\hline T. dominicensis & 0 & .5 & 8.5 & 3 \\
\hline T. forficatus & 3 & 3 & 8.5 & .5 \\
\hline T. melancholicus & 0 & 2.5 & 7.5 & 2 \\
\hline T. tyrannus & 0 & .5 & 7.5 & 4 \\
\hline$T$. verticalis & 0 & 2.5 & 9 & .5 \\
\hline T. vociferans & 0 & 2.5 & 9 & .5 \\
\hline
\end{tabular}

Note.-Values in parentheses give the number of species averaged. The generic averages were converted to proportions, and the arcsine of the square root of the proportion was used in the analysis.

various evolutionary assumptions. The comparison of observed and expected correlations is made via a $Z$ score. Simulations were performed by the PDSIMUL module of the Phenotypic Diversity Analysis Program (Garland et al. 1993). The simulation "evolves" the traits up the given phylogeny by drawing changes from a bivariate normal probability distribution set to have a mean change of zero and an intertrait correlation of zero for each analysis. The variance of the distribution was set such that the variance of the tip values of the simulated data would be similar to that of the real data for Brownian motion simulations. However, because the data consist of transformed proportions, the simulations were bounded such that the traits could not evolve either below zero or above 1.5708 (i.e., the arcsine of the square root of zero and one, respectively). If a change was drawn during a simulation that would result in the traits exceeding these bounds, that change was discarded and replaced by another randomly selected change (see Garland et al. 1993).

Different simulation models were used to incorporate different models of evolutionary change. Evolution by random genetic drift both with and without stabilizing selection was modeled. Random genetic drift without stabilizing selection was modeled as a Brownian motion process in which successive changes were independent of each other and of the starting value. Stabilizing selection may be a more realistic model for many traits, including sexually selected ones. Sexually selected traits are often viewed as stabilized by the counteracting forces of directional sexual selection for greater trait expression and directional natural selection for lesser trait expression. Stabilizing selection was modeled as a Brownian motion process with the addition of a linear force that tends to return the traits toward an adaptive peak (Felsenstein 1988; Garland et al. 1993). These are referred to as Ornstein-Uhlenbeck models. The strength of stabilizing selection can 
range from nonexistent to infinitely strong. I modeled both fairly weak and fairly strong stabilizing selection. The stabilizing selection parameters were equal to the inverse of the total tree height for weak stabilizing selection and 10 times this for strong stabilizing selection (for discussion, see Garland et al. 1993 and the PDSIMUL documentation). The values for the adaptive peaks were set equal to the clades' starting trait values (i.e., the mean of the tip values) and were assumed not to change.

Both gradual change and speciational change were modeled for all of these methods (i.e., for both independent contrasts and computer simulations). Under gradual models, the expected amount of change on a branch is proportional to the length of that branch; for speciational change, all branches are set to equal length. The independent contrasts from speciational models may not prove to be adequately standardized. Transformations, however, would nullify the assumption of the speciational model. Therefore, even when contrasts from the speciational independent contrasts methods were not adequately standardized, the branch lengths were not transformed (i.e., the speciational assumption was retained). In these instances, the resulting correlations are less trustworthy, as all data points may not receive equal weight.

Combining the different analysis methods and their evolutionary assumptions gives a total of eight different methods for testing the correlated evolution of color origin and sexual dichromatism. These are as follows: gradual and speciational independent contrasts, gradual and speciational Brownian motion simulations, and gradual and speciational Ornstein-Uhlenbeck simulations with both weak and strong stabilizing selection. Together these methods incorporate a rather wide range of evolutionary scenarios.

Analyses were performed on the entire clade of passerines and were performed separately for the subclades Tyrannidae, Corvoidea, Sylvioidea, Muscicapoidea, and Passeroidea as defined in Sibley and Ahlquist (1990). Only genera with phylogenetic information in Sibley and Ahlquist (1990, pp. 855-870) were used; genera for which no data were available were deleted from the phylogeny. The difference in delta $\mathrm{T}_{50} \mathrm{H}$ values between two nodes (or a node and a tip) was used for the length of the branch connecting the nodes. Separate analyses were performed for carotenoid, melanin, and structural colors. One-tailed $P$ values are reported for the correlation between dichromatism and carotenoids; two-tailed $P$ values are reported for the correlations between dichromatism and melanin and dichromatism and structurally derived colors. One-tailed $P$ values are preferred for the carotenoid analyses, as the a priori hypothesis is explicitly directional, predicting positive correlations.

\section{RESULTS}

\section{Independent Contrasts Methods}

The results of the independent contrasts methods are given in table 2 and figures 1-3. In passerines as a whole, no branch length transformations were found to be necessary $(P>.05$ for all correlations of contrasts with their standard 
TABLE 2

Results of IndePendent Contrasts Methods

\begin{tabular}{|c|c|c|c|c|c|c|}
\hline & \multicolumn{2}{|c|}{ CARotenoid } & \multicolumn{2}{|c|}{ Melanin } & \multicolumn{2}{|c|}{ Structural } \\
\hline & $r$ & df & $r$ & df & $r$ & df \\
\hline \multicolumn{7}{|l|}{ All passerines: } \\
\hline Gradual & .340 & $66-70^{* *}$ & -.267 & $66-70 \dagger$ & -.048 & 66-70 (NS) \\
\hline Speciational & .359 & $66^{* *}, 67-70^{* * *}$ & -.287 & $66-70 \dagger$ & -.050 & $66-70$ (NS) \\
\hline \multicolumn{7}{|l|}{ Tyrannidae: } \\
\hline Gradual & .645 & $6-8^{*}$ & -.354 & 6-8 (NS) & -.833 & $6-8+\dagger$ \\
\hline Speciational & .803 & $6-8^{* *}$ & -.401 & 6-8 (NS) & -.857 & $6-8+\dagger$ \\
\hline \multicolumn{7}{|l|}{ Corvoidea: } \\
\hline Gradual & .105 & 6-8 (NS) & -.024 & 6-8 (NS) & .020 & 6-8 (NS) \\
\hline Speciational & .276 & 6-8 (NS) & .276 & 6-8 (NS) & -.300 & 6-8 (NS) \\
\hline \multicolumn{7}{|l|}{ Sylvioidea: } \\
\hline Gradual & .329 & 14 (NS) & -.427 & 14 (NS) & .217 & 14 (NS) \\
\hline Speciational & .431 & $14^{*}$ & -.364 & 14 (NS) & .115 & 14 (NS) \\
\hline \multicolumn{7}{|l|}{ Muscicapoidea: } \\
\hline Gradual & -.233 & 11 (NS) & .102 & 11 (NS) & -.082 & 11 (NS) \\
\hline Speciational & -.397 & 11 (NS) & -.392 & 11 (NS) & .460 & 11 (NS) \\
\hline \multicolumn{7}{|l|}{ Passeroidea: } \\
\hline Gradual & .461 & $21^{*}$ & -.357 & 21 (NS) & -.223 & 21 (NS) \\
\hline Speciational & .487 & $21^{* *}$ & -.383 & 21 (NS) & -.252 & 21 (NS) \\
\hline
\end{tabular}

Note. - The correlation of independent contrasts is indicated by $r$. The degrees of freedom encompass a range for some groups. This is a result of polytomies (see text).

$* P<.05$, one-tailed test.

** $P<.01$, one-tailed test.

*** $P<.001$, one-tailed test.

$\dagger P<.05$, two-tailed test.

$\dagger \dagger P<.01$, two-tailed test.

deviations) for tests assuming gradual change. For speciational tests, the dichromatism contrasts were not adequately standardized (correlation between the absolute value of the standardized contrasts and their standard deviations: $r=$ 0.282 , df $=65-69, P<.05)$. Assuming gradual evolution, changes in carotenoid coloration correlate positively with changes in dichromatism $(r=0.340, \mathrm{df}=$ 66-70, $P<.01)$. Changes in melanins correlate negatively with changes in dichromatism $(r=-0.267, \mathrm{df}=66-70, P<.05)$. Changes in structural coloration do not correlate significantly with changes in dichromatism $(r=-0.048$, df $=$ 66-70, $P>.05$ ). Despite the poor standardization of the dichromatism contrasts, the results of the speciational model are qualitatively identical (carotenoids: $r=$ 0.359, $P<.01$; melanins: $r=-0.287, P<.05$; structurals: $r=-0.050, P>$ .05 ; $\mathrm{df}=66-70$ ).

In the Tyrannidae, contrasts were adequately standardized both for the gradual and for the speciational model ( $P>.05$ for all comparisons). Changes in carotenoid coloration correlate positively with changes in dichromatism (gradual model: $r=0.645, P<.05$, df $=6-8$; speciational model: $r=0.803, P<.01$, $\mathrm{df}=6-8)$. Changes in melanin coloration do not correlate significantly with changes in dichromatism (gradual model: $r=-0.354, P>.05$, $\mathrm{df}=6-8$; specia- 


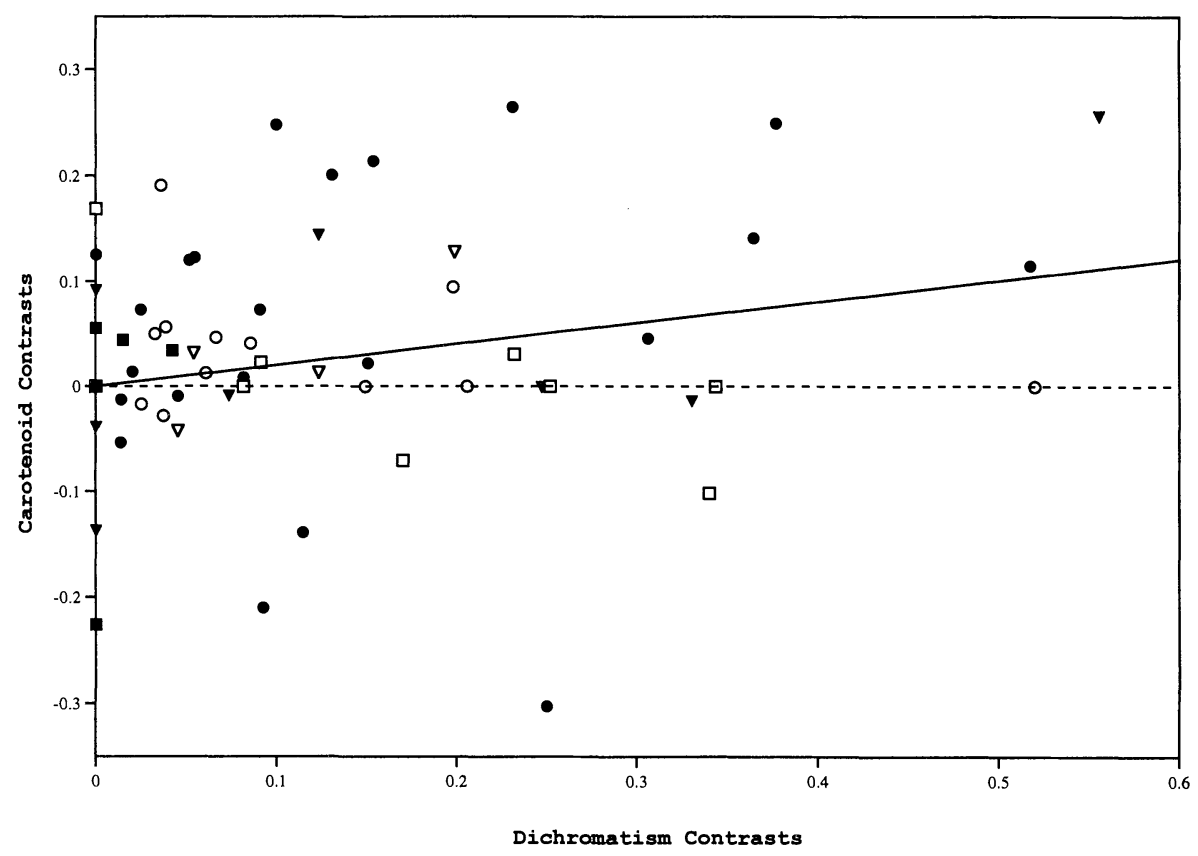

Fig. 1.-The relationship between standardized independent contrasts of carotenoid coloration and dichromatism. Thirteen points overlap at the origin $(0,0)$; all others are shown, although several are partially obscured. Plotting symbols indicate contrasts within subclades: filled and open squares represent contrasts within the Corvoidea and the Muscicapoidea, respectively; filled and open circles represent contrasts within the Passeroidea and the Sylvioidea, respectively; filled and open triangles represent contrasts within the Tyrannidae and basal contrasts among the five subclades, respectively.

tional model: $r=-0.401, P>.05, \mathrm{df}=6-8$ ). Changes in structural coloration correlate negatively with changes in dichromatism (gradual model: $r=-0.833$, $P<.01$, df $=6-8$; speciational model: $r=-0.857, P<.01$, df $=6-8$ ).

In the Corvoidea, contrasts were not adequately standardized for the gradual model (dichromatism contrasts: $r=0.727$; melanin contrasts: $r=-0.711$; structural contrasts: $r=-0.674$, $\mathrm{df}=5-7, P<.05$ ) or for the speciational model (dichromatism contrasts: $r=0.675$, $\mathrm{df}=5-7, P<.05$ ). For the gradual model, branch lengths were transformed by raising them to the fourth power and then rescaling the total tree height back to the original total height. This resulted in adequate standardization for all traits. No significant correlations between changes in coloration and changes in dichromatism were found (gradual model: carotenoid $r=0.105$, melanin $r=-0.024$, structural $r=0.020$; speciational model: carotenoid $r=0.276$, melanin $r=0.276$, structural $r=-0.300 ; \mathrm{df}=$ $6-8, P>.05$ for all tests).

In the Sylvioidea, dichromatism contrasts were not adequately standardized for the gradual model $(r=-0.532, \mathrm{df}=13, P<.05)$. Contrasts were adequately 


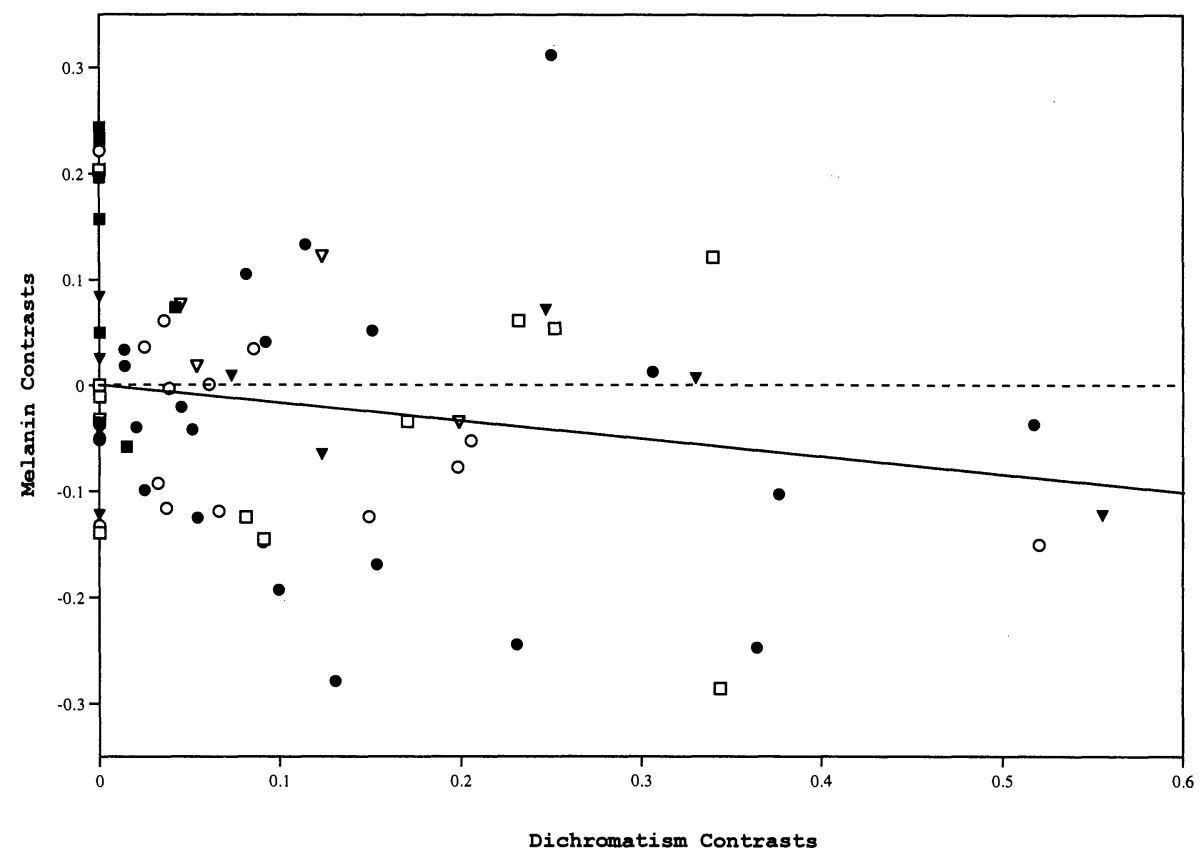

FIG. 2.-The relationship between standardized independent contrasts of melanin coloration and dichromatism. All points are shown, although several are partially obscured. Plotting symbols are as in figure 1.

standardized for all traits in the speciational model. For the gradual model, branch lengths were square-root transformed. This resulted in adequate standardization of contrasts for all traits. Changes in carotenoids correlate positively with changes in dichromatism for the speciational, but not the gradual model (gradual model: $r=0.329$, df $=14, P>.05$; speciational model: $r=0.431$, df $=14, P<.05$ ). No significant results were found for either melanin or structural colors (gradual model: melanin $r=-0.427$, structural $r=0.217$; speciational model: melanin $r=-0.364$, structural $r=0.115 ; \mathrm{df}=14, P>.05$ for all tests).

In the Muscicapoidea, dichromatism contrasts were not adequately standardized for the gradual model $(r=0.645$, df $=10, P<.05)$. Contrasts were adequately standardized for all traits in the speciational model. For the gradual model, branch lengths were transformed by raising them to the fourth power and then rescaling the total tree height back to the original total height. This resulted in adequate standardization for all traits. No significant correlations between changes in coloration and changes in dichromatism were found (gradual model: carotenoid $r=-0.233$, melanin $r=0.102$, structural $r=-0.082$; speciational model: carotenoid $r=-0.397$, melanin $r=-0.392$, structural $r=0.460$; df $=$ $11, P>.05$ for all tests).

In the Passeroidea, dichromatism contrasts were not adequately standardized 


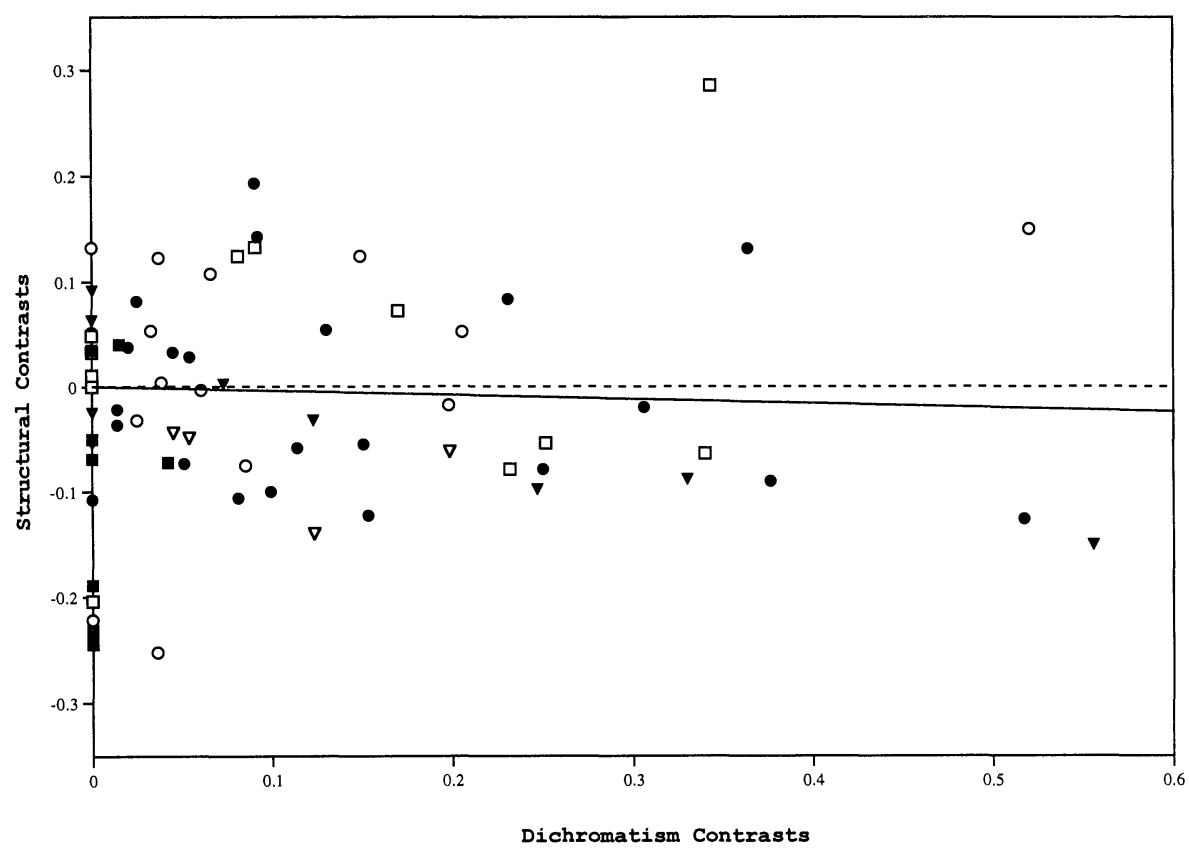

FIG. 3.-The relationship between standardized independent contrasts of structural coloration and dichromatism. Two points overlap on the $Y$-axis $(0,-0.24)$; all other points are shown, although several are partially obscured. Plotting symbols are as in figure 1 .

for the gradual model $(r=-0.427$, df $=20, P<.05)$. For the speciational model, carotenoid contrasts were not adequately standardized $(r=0.440$, $\mathrm{df}=$ $20, P<.05)$. For the gradual model, branch lengths were square-root transformed. This resulted in adequate standardization of contrasts for all traits. Changes in carotenoids correlate positively with changes in dichromatism (gradual model: $r=0.461$; speciational model: $r=0.487$; $\mathrm{df}=21, P<.05$ gradual model, $P<.01$ speciational model). No significant results were found for either melanin or structural colors (gradual model: melanin $r=-0.357$, structural $r=$ -0.223 ; speciational model: melanin $r=-0.383$, structural $r=-0.252$; $\mathrm{df}=$ $21, P>.05$ for all tests).

\section{Simulation Methods}

The results of the simulation methods are presented in table 3 . The passerines as a whole show a positive Pearson product-moment correlation between carotenoids and dichromatism ( $r=0.524, P<.05$ for all analysis methods). Furthermore, all five subclades show positive correlations between carotenoids and dichromatism (binomial sign test, $P<.05$ ). No significant association between melanins and dichromatism was found in passerines as a whole $(r=-0.208$, $P>.05$ for all analysis methods). However, all five subclades show a negative 
TABLE 3

Results of Computer Simulation Methods

\begin{tabular}{|c|c|c|}
\hline Analysis Group and Method & Mean (SD) & $Z$ Score \\
\hline \multicolumn{3}{|l|}{$\begin{array}{l}\text { All passerines (number of } \\
\text { tips }=72 \text { ): }\end{array}$} \\
\hline \multicolumn{3}{|l|}{ Carotenoid $(r=.524)$} \\
\hline GB & $-.003(.198)$ & $2.662 * *$ \\
\hline SB & $.033(.213)$ & $2.305^{*}$ \\
\hline GOUW & $.013(.162)$ & $3.154^{* * *}$ \\
\hline GOUS & $-.003(.123)$ & $4.285^{* * *}$ \\
\hline SOUW & $.010(.171)$ & $3.006^{* *}$ \\
\hline SOUS & $.001(.122)$ & $4.287 * * *$ \\
\hline \multicolumn{3}{|l|}{ Melanin $(r=-.208)$} \\
\hline GB & $.008(.203)$ & $-1.064(\mathrm{NS})$ \\
\hline SB & $.000(.231)$ & -.900 (NS) \\
\hline GOUW & $.013(.171)$ & $-1.292(\mathrm{NS})$ \\
\hline GOUS & $.003(.130)$ & $-1.623(\mathrm{NS})$ \\
\hline SOUW & $-.003(.204)$ & $-1.005(\mathrm{NS})$ \\
\hline SOUS & $.001(.122)$ & $-1.713(\mathrm{NS})$ \\
\hline \multicolumn{3}{|l|}{ Structural $(r=-.285)$} \\
\hline GB & $-.002(.203)$ & $-1.394(\mathrm{NS})$ \\
\hline SB & $.023(.222)$ & $-1.387(\mathrm{NS})$ \\
\hline GOUW & $.004(.162)$ & $-1.784(\mathrm{NS})$ \\
\hline GOUS & $.003(.130)$ & $-2.215 \dagger$ \\
\hline SOUW & $-.003(.204)$ & $-1.382(\mathrm{NS})$ \\
\hline SOUS & $.001(.122)$ & $-2.344 \dagger$ \\
\hline \multicolumn{3}{|l|}{$\begin{array}{l}\text { Tyrannidae (number of tips } \\
=10 \text { ): }\end{array}$} \\
\hline \multicolumn{3}{|l|}{ Carotenoid $(r=.591)$} \\
\hline GB & $.000(.354)$ & $1.670^{*}$ \\
\hline SB & $.058(.359)$ & 1.485 (NS) \\
\hline GOUW & $.022(.355)$ & 1.603 (NS) \\
\hline GOUS & $.005(.347)$ & $1.689^{*}$ \\
\hline SOUW & $-.001(.359)$ & $1.649^{*}$ \\
\hline SOUS & $-.015(.328)$ & $1.848^{*}$ \\
\hline \multicolumn{3}{|l|}{ Melanin $(r=-.177)$ : } \\
\hline GB & $.001(.367)$ & -.485 (NS) \\
\hline SB & $-.009(.382)$ & -.440 (NS) \\
\hline GOUW & $.006(.352)$ & -.486 (NS) \\
\hline GOUS & $.005(.347)$ & -.525 (NS) \\
\hline SOUW & $-.001(.359)$ & -.490 (NS) \\
\hline SOUS & $-.015(.328)$ & -.494 (NS) \\
\hline \multicolumn{3}{|l|}{ Structural $(r=-.905)$ : } \\
\hline GB & $.001(.372)$ & $-2.436 \dagger$ \\
\hline SB & $.023(.359)$ & $-2.585+\dagger$ \\
\hline GOUW & $.002(.340)$ & $-2.668 \dagger \dagger$ \\
\hline GOUS & $.005(.347)$ & $-2.623+\dagger$ \\
\hline SOUW & $-.001(.359)$ & $-2.518 \dagger$ \\
\hline SOUS & $-.015(.328)$ & $-2.713 \dagger \dagger$ \\
\hline \multicolumn{3}{|l|}{$\begin{array}{l}\text { Corvoidea (number of tips } \\
=10 \text { ): }\end{array}$} \\
\hline \multicolumn{3}{|l|}{ Carotenoid $(r=.298):$} \\
\hline GB & $-.002(.355)$ & .845 (NS) \\
\hline SB & $.134(.360)$ & .456 (NS) \\
\hline GOUW & $.034(.341)$ & .774 (NS) \\
\hline GOUS & $.007(.337)$ & .864 (NS) \\
\hline SOUW & $.043(.349)$ & .731 (NS) \\
\hline SOUS & $-.006(.344)$ & $.884(\mathrm{NS})$ \\
\hline
\end{tabular}


TABLE 3 (Continued)

\begin{tabular}{|c|c|c|}
\hline Analysis Group and Method & Mean (SD) & $Z$ Score \\
\hline \multicolumn{3}{|l|}{ Melanin $(r=-.041)$ : } \\
\hline $\mathrm{GB}$ & $.010(.365)$ & $-.140(\mathrm{NS})$ \\
\hline SB & $.000(.378)$ & -.109 (NS) \\
\hline GOUW & $.002(.342)$ & $-.126(\mathrm{NS})$ \\
\hline GOUS & $.007(.355)$ & -.135 (NS) \\
\hline SOUW & $.003(.344)$ & -.128 (NS) \\
\hline SOUS & $-.006(.344)$ & -.102 (NS) \\
\hline \multicolumn{3}{|l|}{ Structural $(r=-.066)$ : } \\
\hline GB & $-.007(.356)$ & $-.166(\mathrm{NS})$ \\
\hline SB & $-.011(.379)$ & -.145 (NS) \\
\hline GOUW & $-.001(.345)$ & $-.188(\mathrm{NS})$ \\
\hline GOUS & $.007(.355)$ & -.206 (NS) \\
\hline SOUW & $.003(.349)$ & $-.198(\mathrm{NS})$ \\
\hline SOUS & $-.006(.344)$ & -.174 (NS) \\
\hline \multicolumn{3}{|l|}{$\begin{array}{l}\text { Sylvioidea (number of tips } \\
\qquad=16 \text { ): }\end{array}$} \\
\hline \multicolumn{3}{|l|}{ Carotenoid $(r=.508)$} \\
\hline GB & $.003(.290)$ & $1.741^{*}$ \\
\hline SB & $.046(.317)$ & $1.457(\mathrm{NS})$ \\
\hline GOUW & $.014(.275)$ & $1.796^{*}$ \\
\hline GOUS & $-.004(.283)$ & $1.809^{*}$ \\
\hline SOUW & $.007(.274)$ & $1.829 *$ \\
\hline SOUS & $-.005(.254)$ & $2.020^{*}$ \\
\hline \multicolumn{3}{|l|}{ Melanin $(r=-.457)$ : } \\
\hline GB & $.005(.305)$ & $-1.515(\mathrm{NS})$ \\
\hline SB & $.013(.355)$ & -1.324 (NS) \\
\hline GOUW & $.003(.286)$ & -1.608 (NS) \\
\hline GOUS & $-.005(.286)$ & -1.580 (NS) \\
\hline SOUW & $.017(.301)$ & $-1.575(\mathrm{NS})$ \\
\hline SOUS & $-.005(.254)$ & -1.780 (NS) \\
\hline \multicolumn{3}{|l|}{ Structural $(r=.153)$ : } \\
\hline GB & $.010(.308)$ & .464 (NS) \\
\hline SB & $.016(.341)$ & .402 (NS) \\
\hline GOUW & $.007(.282)$ & .518 (NS) \\
\hline GOUS & $-.005(.286)$ & .552 (NS) \\
\hline SOUW & $.008(.307)$ & .472 (NS) \\
\hline \multirow{2}{*}{\multicolumn{3}{|c|}{$\begin{array}{l}\text { Muscicapoidea (number of } \\
\text { tips = 13): }\end{array}$}} \\
\hline & & \\
\hline \multicolumn{3}{|l|}{ Carotenoid $(r=.076)$} \\
\hline GB & $.002(.322)$ & .230 (NS) \\
\hline SB & $.059(.328)$ & .052 (NS) \\
\hline GOUW & $-.012(.310)$ & .284 (NS) \\
\hline GOUS & $-.005(.306)$ & .265 (NS) \\
\hline SOUW & $.007(.304)$ & .227 (NS) \\
\hline SOUS & $.012(.288)$ & $.222(\mathrm{NS})$ \\
\hline \multicolumn{3}{|l|}{ Melanin $(r=-.272)$} \\
\hline GB & $-.001(.329)$ & -.824 (NS) \\
\hline SB & $-.046(.343)$ & -.659 (NS) \\
\hline GOUW & $.007(.305)$ & -.915 (NS) \\
\hline GOUS & $-.004(.307)$ & -.873 (NS) \\
\hline SOUW & $.003(.313)$ & -.879 (NS) \\
\hline SOUS & $-.001(.285)$ & -.951 (NS) \\
\hline
\end{tabular}


TABLE 3 (Continued)

\begin{tabular}{lcc}
\hline \hline Analysis Group and Method & Mean (SD) & $Z$ Score \\
\hline Structural $(r=.258):$ & $.010(.327)$ & .758 (NS) \\
GB & $.022(.334)$ & .707 (NS) \\
SB & $.011(.305)$ & $.810(\mathrm{NS})$ \\
GOUW & $-.004(.307)$ & .853 (NS) \\
GOUS & $.019(.303)$ & .789 (NS) \\
SOUW & $-.001(.285)$ & .909 (NS) \\
SOUS & & \\
Passeroidea (number of tips & & \\
= 23): & & \\
Carotenoid $(r=.537):$ & $.001(.247)$ & $2.170^{*}$ \\
GB & $.012(.279)$ & $1.882^{*}$ \\
SB & $.016(.238)$ & $2.189^{*}$ \\
GOUW & $.005(.217)$ & $2.452^{* *}$ \\
GOUS & $.013(.259)$ & $2.023^{*}$ \\
SOUW & $.003(.208)$ & $2.567^{* *}$ \\
SOUS & & \\
Melanin $(r=-.299):$ & $.007(.261)$ & -1.172 (NS) \\
GB & $.005(.285)$ & -1.067 (NS) \\
SB & $.002(.243)$ & -1.239 (NS) \\
GOUW & $.005(.217)$ & -1.401 (NS) \\
GOUS & $.003(.272)$ & -1.110 (NS) \\
SOUW & $.003(.208)$ & -1.452 (NS) \\
SOUS & & \\
Structural $(r=-.497):$ & $.004(.253)$ & $-1.980 \dagger$ \\
GB & $-.004(.283)$ & $-1.742(\mathrm{NS})$ \\
SB & $.005(.236)$ & $-2.127 \dagger$ \\
GOUW & $.005(.217)$ & $-2.313 \dagger$ \\
GOUS & $.012(.268)$ & -1.899 (NS) \\
SOUW & $.003(.208)$ & $-2.404 \dagger$ \\
SOUS & & \\
\hline
\end{tabular}

NoTE.-The observed Pearson product-moment correlation between coloration and sexual dichromatism $(r)$ and the mean (SD) of 1,000 simulations are shown. Methods: GB, gradual Brownian motion; SB, speciational Brownian motion; GOUW, gradual Ornstein-Uhlenbeck weak; GOUS, gradual Ornstein-Uhlenbeck strong; SOUW, speciational Ornstein-Uhlenbeck weak; SOUS, speciational Ornstein-Uhlenbeck strong; all simulations were bounded (see text).

${ }^{*} P<.05$, one-tailed test.

** $P<.01$, one-tailed test.

$* * * P<.001$, one-tailed test.

$\dagger P<.05$, two-tailed test.

$\dagger \dagger P<.01$, two-tailed test. 


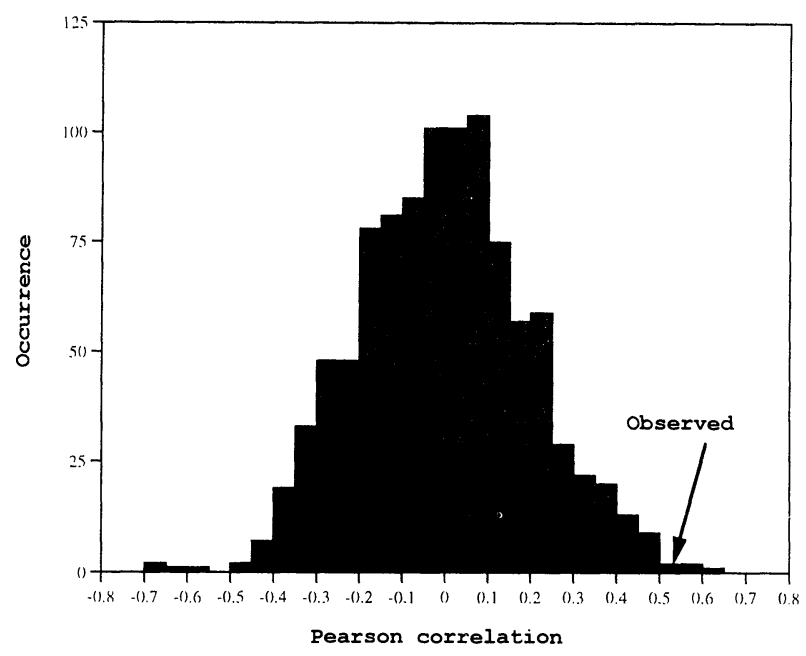

Fig. 4.-The observed correlation between the tip values of carotenoid-derived coloration and dichromatism, and the distribution of correlations of tip values of data simulated under the gradual Brownian motion model.

relationship (binomial sign test, $P<.05$ ). Structural coloration is negatively correlated with dichromatism in passerines as a whole $(r=-0.285, P<.05$ for two analysis methods, $P>.05$ for four analysis methods). The two analysis methods yielding significant results both assume fairly strong stabilizing selection on plumage coloration. In three of the five subclades, structural colors are negatively correlated with dichromatism (binomial sign test, $P>.05$ ). Figures 4-6 show the observed tip correlation and the distribution of the correlations of the simulated tip data for passerines as a whole, assuming gradual Brownian motion.

In the Tyrannidae, carotenoids correlate positively with dichromatism $(r=$ $0.591, P<.05$ ) for four analysis methods. Neither the speciational Brownian motion nor the weak gradual Ornstein-Uhlenbeck methods give significant results. Melanins show a weak, nonsignificant negative correlation $(r=-0.177$, $P>.05$ for all methods). Structural coloration is strongly negatively correlated with dichromatism ( $r=-0.905, P<.05$ for all methods).

In the Corvoidea, no significant relationships were found (carotenoids: $r=$ $0.298, P>.05$ for all methods; melanins: $r=-0.041, P>.05$ for all methods; structurals: $r=-0.066, P>.05$ for all methods).

In the Sylvioidea, carotenoids correlate positively with dichromatism $(r=$ $0.508, P<.05$ for all methods except speciational Brownian motion, where $P>$ $.05)$. Neither melanins nor structural colors significantly correlate with dichromatism (melanins: $r=-0.457, P>.05$ for all methods; structurals: $r=0.153, P$ $>.05$ for all methods).

In the Muscicapoidea, no significant relationships were found (carotenoids: $r=0.076, P>.05$ for all methods; melanins: $r=-0.272, P>.05$ for all methods; structurals: $r=0.258, P>.05$ for all methods). 


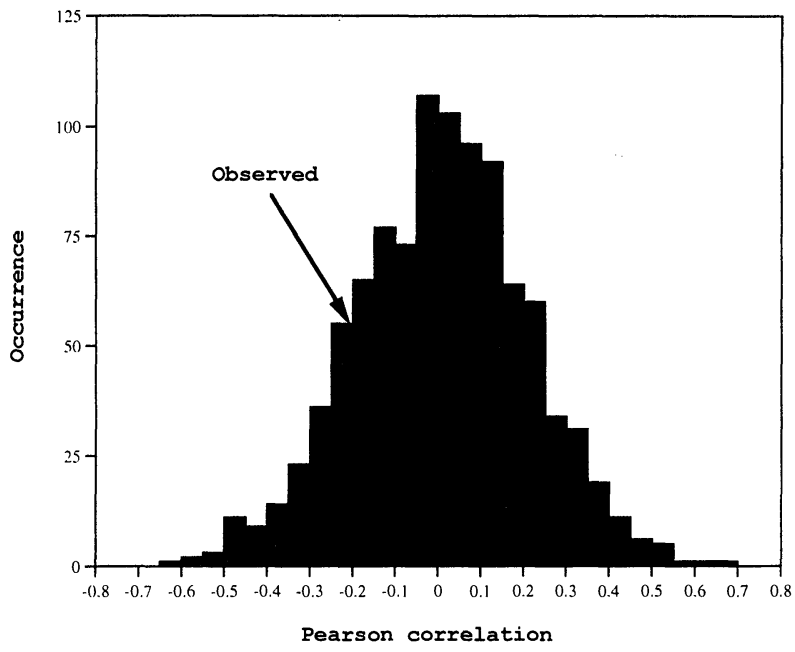

FIG. 5.- The observed correlation between the tip values of melanin-derived coloration and dichromatism, and the distribution of correlations of tip values of data simulated under the gradual Brownian motion model.

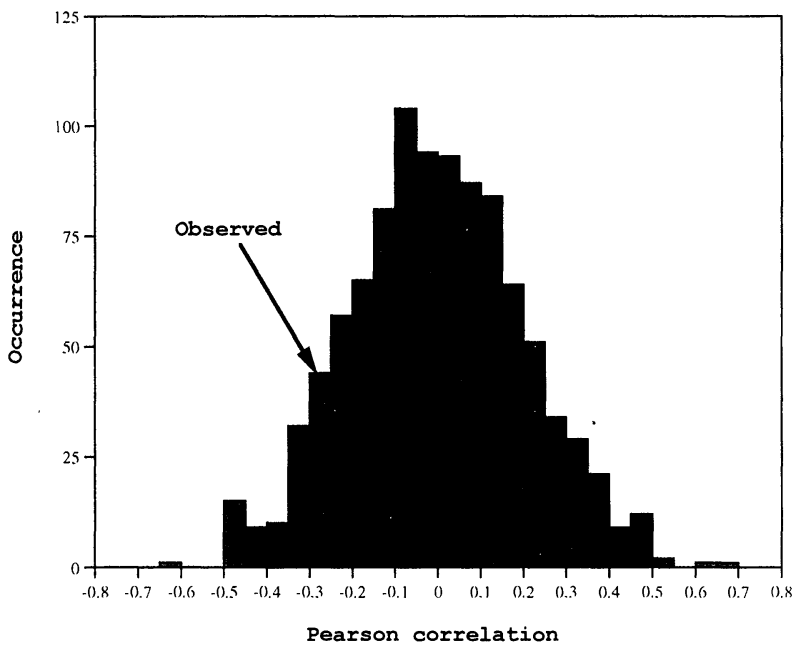

Fig. 6.-The observed correlation between the tip values of structurally derived coloration and dichromatism, and the distribution of correlations of tip values of data simulated under the gradual Brownian motion model. 
In the Passeroidea, carotenoids correlate positively with dichromatism ( $r=$ $0.537, P<.05$ for all methods). Melanins do not correlate significantly with dichromatism $(r=-0.299, P>.05$ for all methods). Structural colors negatively correlate with dichromatism $(r=-0.497, P<.05$ for four methods, $P>.05$ for both the speciational Brownian motion and the weak speciational OrnsteinUhlenbeck methods).

\section{DISCUSSION}

The results for passerines as a whole are supportive of the hypothesis that carotenoids should correlate positively with sexual dichromatism, whereas melanin and structurally produced colors may not. This observed pattern is attributable to three of the five subclades, although all five subclades show positive correlations (for the simulation methods). It is not at all surprising that no significant results were found in the Corvoidea, as only one genus shows any sexual dichromatism. The results for the Muscicapoidea are more surprising. It is difficult to interpret these results because they depend somewhat on the analysis method used and are not statistically significant. Overall, the increase in carotenoids has been at the expense of both melanins and structural coloration. In the Tyrannidae and the Passeroidea, it appears that carotenoids have replaced mainly structural coloration. However, for passerines as a whole, the independent contrasts methods suggest that melanins have been replaced, and the simulation methods suggest (weakly) that structural colors have been replaced. The carotenoid results, combined with the generally negative correlations for both melanin and structurally derived coloration, suggest that sexual selection has favored carotenoid coloration. Clearly this does not prove that sexual selection has operated on the basis of a condition-dependent honest indicator of quality; however, one major prediction of the carotenoids-as-honest-signals hypothesis is supported.

For carotenoids to be honest signals, carotenoids should be in some way limiting. Whether or not carotenoids are limited in the wild is a matter of some debate (Hill 1994a; Hudon 1994). To date, very few empirical studies have addressed this issue. Several studies of passerine birds have shown that the degree of carotenoid ornamentation is associated with differences in dietary intake or environmental availability of carotenoids (Slagsvold and Lifjeld 1985; Partali et al. 1987; Hill and Montgomerie 1994; Hill et al. 1994; Ryan et al. 1994). For a carotenoid signaling system to be honest, carotenoids need be available but not superabundant within the normal diet. Insectivorous and granivorous species are more likely to meet these requirements than are largely carnivorous or frugivorous species. Carnivorous species may not acquire sufficient excess carotenoids for a signaling function to evolve, whereas frugivorous species may easily acquire such large quantities of carotenoids that they may no longer be indicative of health or foraging or competitive abilities.

Carotenoids can become limiting for reasons other than environmental availability. If physiological condition affects foraging, then ornamental carotenoids have the potential to reflect physiological condition, such as disease status prior 
to the last molt. Disease can also directly affect carotenoids. In fact, various parasites have been shown to decrease carotenoid pigmentation of infected hosts. The amount of carotenoid coloration in three-spined sticklebacks, Gasterosteus aculeatus, has been shown to correlate positively with male condition and freedom from parasites (Milinski and Bakker 1990). The red eye coloration of red jungle fowl, Gallus gallus, which is partially carotenoid based, is negatively affected by an intestinal parasite (Zuk et al. 1990a). In domestic fowl, carotenoid levels are negatively affected by infection with coccidia (Ruff et al. 1974). The carotenoid spots of guppies, Poecilia reticulata, are negatively affected by at least one type of parasitic infection (Houde and Torio 1992). Disease states are associated with reduced carotenoid activity in humans. Intestinal parasites, liver, kidney, and thyroid diseases, and systemic infections and stress reduce circulating levels of vitamin A or its derivatives (reviewed in Underwood 1984).

Carotenoids are the essential vitamin A precursors (Pitt 1971; Underwood 1984). Vitamin A and its derivatives are involved in growth, vision, cell differentiation, spermatogenesis, and immune function (Dennert 1984; Moon and Itri 1984; Roberts and Sporn 1984; Underwood 1984; Mather and Phillips 1986). This has two important implications. First, display carotenoids should be in excess of those required physiologically. Discussions of whether or not carotenoids are limiting must include baseline physiological levels as well as ornamental requirements. Second, we should not expect that the mechanisms of carotenoid manipulation, storage, and deposition are maximized solely for display purposes. If carotenoids are, or periodically become, limiting, then individuals should maintain biochemical pathways that reserve carotenoids for physiological use, rather than exclusively maximize display independent of physiological requirements. Absolute maximization of sexual display, at the expense of maintenance, is probably very rare in iteroparous species.

Phylogenetic analyses are explicitly historical. Correlated changes in traits imply past selection, or genetic correlation and covariance (Leroi et al. 1994); the results need not imply current selection for carotenoids in sexually dichromatic species. Nonetheless, examples of current selection can provide additional support for the hypothesis. Before assessing these examples, it is important to emphasize that the results would be predicted independently of whether male-male competition or female choice is the stronger sexually selective force. This is because it should pay both sexes to heed signals that are reliably associated with quality (Butcher and Rohwer 1989).

Current selection along the lines proposed here has been demonstrated in a few instances. In fish, female three-spined sticklebacks, G. aculeatus, prefer males with greater carotenoid-derived red coloration (Bakker and Mundwiler 1994). In guppies, $P$. reticulata, females prefer males with more and brighter carotenoid-derived orange spots (Endler 1983; Kodric-Brown 1985, 1989). In birds, female house finches, Carpodacus mexicanus, prefer males with more carotenoid-derived red plumage (Hill 1990, 1991, 1994b). In American goldfinches, Carduelis tristis, females prefer males with brighter yellow plumage and orange 
bill color, which are carotenoid derived (Johnson et al. 1993). The bright yellow underwing of male village weavers, Ploceus cucullatus, is important in attracting females to nest sites (Collias et al. 1979). The bright yellow is known to be carotenoid derived (Fox 1976). The bright red epaulets of male red-winged blackbirds, Agelaius phoeniceus, are important in male-male competition for territories (Peek 1972; Smith 1972; Røskaft and Rohwer 1987). On the basis of appearance, the epaulets seem likely to be carotenoid derived, but to my knowledge this has not been tested biochemically. In red jungle fowl, G. gallus, plumage color is caused by melanins (Witschi 1961), whereas eye color is affected by carotenoids (Fox 1976). The effects of plumage on female choice are unclear (contrast Zuk et al. $1990 b$ with Ligon and Zwartjes 1995), although females do seem to prefer males with redder eyes (Zuk et al. 1990b).

Mating system and male parental care are not controlled for in this study. Polygynous mating systems are not invariably associated with strong sexual dimorphism. In fact, nearly $25 \%$ of avian lekking species are monomorphic (Trail 1990). The effects of early breeding and potential second clutches (Darwin 1871; Selander 1972), male-biased sex ratios (Darwin 1871; Lack 1954; Witschi 1961), possible cuckoldry via prepairing copulation (Moore and McDonald 1993), and extrapair copulations (Ford 1983; Birkhead 1987; Birkhead et al. 1988; Møller and Birkhead 1994) are argued to be sufficient to promote strong sexual selection. Parental care does not vary extensively among North American passerines (Verner and Willson 1969). In a comparative test of the Hamilton and Zuk (1982) hypothesis, Johnson (1991) found no difference in the conspicuousness of monogamous and polygynous North American passerine families or subfamilies. Among the families or subfamilies that do show variation in sex-specific incubation, no association with male plumage conspicuousness was found. Johnson's analysis is especially relevant to this study, as it reserved the maximally conspicuous plumage scores for bright reds and yellows (i.e., probable carotenoids) and blues, attempted to control for phylogeny (albeit in a manner different from this study), and analyzed North American passerines, and so consists of a sample very similar to that used here. Similarly, in a review of European passerines, Møller (1986) found that monogamous and polygynous species were equally dimorphic in plumage brightness. Thus, the effects of these potentially confounding variables are thought to be minimal or nonexistent.

The association between carotenoid-derived male plumage coloration and sexual dichromatism demonstrated here is easily incorporated into good genes or condition-dependent models of sexual selection. However, two alternate hypotheses need to be addressed. The first is the sensory-bias model of sexual selection (Basolo 1990; Ryan and Keddy-Hector 1992), in which male traits are elaborated solely because of their stimulatory effect on female perceptual or nervous systems. The sensory-bias model would argue that carotenoid-derived plumage was elaborated in males because female perceptual or nervous systems respond more strongly to colors that humans perceive as reds, yellows, and oranges. Such a female bias could be caused by either innate factors or perhaps because of an association between red, yellow, or orange stimuli and important naturally se- 
lected ecological factors, for example, red berries as food sources. The Tyrannidae can serve as a good counterexample to both types of biases. Both innate and ecological biases favoring carotenoid-derived colors are unlikely in insectivorous species because of the potential danger of yellow warning-colored insects, particularly various Hymenoptera. An innate avoidance mechanism is more likely and has been demonstrated for the avoidance of coral snakes by kiskadees (Smith 1977). Despite the foregoing, it remains possible that carotenoids have been favored simply because they are bright.

The second alternative hypothesis that needs consideration is the unprofitable prey model of Baker and Parker (1979). In essence, they propose that brightness in birds evolved to signal to predators that the prey are either noxious, potentially dangerous, or simply alert and aware of the predator, any of which make the prey less valuable to the predator. Krebs (1979) and Lyon and Montgomerie (1985) argue that causation is not clearly established and that the sexual selection hypothesis is not substantially refuted by either Baker and Parker (1979) or Baker and Hounsome (1983). Experimental evidence is scarce and has yet to resolve this issue (Götmark 1993). Nonetheless, the carotenoid results presented here could be interpreted as representing honest signals whether directed by males to other males, females, or predators. The results would then be interpreted in the context of signal selection (Hasson 1990, 1991; Zahavi 1991). If this were the case, then carotenoid-derived plumage should correlate with predation risk.

\section{ACKNOWLEDGMENTS}

This work is in partial fulfillment of the requirements for a Ph.D. in ecology and evolutionary biology at the University of New Mexico. I would like to express my thanks to the members of my dissertation committee, J. H. Brown, A. KodricBrown, and J. D. Ligon for their continued advice and support. I would also like to thank T. Garland, Jr., J. Hudon, and an anonymous reviewer for their valuable help and criticism of a previous version of this work. I am particularly grateful to T. Garland, Jr., for access to the Phenotypic Diversity Analysis Program and for his patience with my questions about it. I receive financial support from a National Science Foundation Graduate Research Fellowship.

LITERATURE CITED

Andersson, M. 1982. Sexual selection, natural selection and quality advertisement. Biological Journal of the Linnean Society 17:375-393.

1986. Evolution of condition-dependent sex ornaments and mating preferences: sexual selection based on viability differences. Evolution 40:804-816.

Baker, R. R., and M. V. Hounsome. 1983. Bird coloration: unprofitable prey model supported by ringing data. Animal Behaviour 31:614-615.

Baker, R. R., and G. A. Parker. 1979. The evolution of bird coloration. Philosophical Transactions of the Royal Society of London B, Biological Sciences 287:63-130.

Bakker, T. C. M., and B. Mundwiler. 1994. Female choice and male red coloration in a natural 
three-spined stickleback (Gasterosteus aculeatus) population. Behavioral Ecology 5:7480 .

Basolo, A. L. 1990. Female preference predates the evolution of the sword in swordtail fish. Science (Washington, D.C.) 250:808-810.

Bennett, A. T. D., I. C. Cuthill, and K. J. Norris. 1994. Sexual selection and the mismeasure of color. American Naturalist 144:848-860.

Birkhead, T. R. 1987. Sperm competition in birds. Trends in Ecology \& Evolution 2:268-272.

Birkhead, T. R., J. Pellat, and F. M. Hunter. 1988. Extra-pair copulation and sperm competition in the zebra finch. Nature (London) 344:60-62.

Brush, A. H. 1978. Avian pigmentation. Pages 141-164 in A. H. Brush, ed. Chemical zoology. Vol. 10. Aves. Academic Press, New York.

Butcher, G. S., and S. Rohwer. 1989. The evolution of conspicuous and distinctive coloration for communication in birds. Current Ornithology 6:51-108.

Collias, E. C., N. E. Collias, C. H. Jacobs, F. McAlary, and J. T. Fujimoto. 1979. Experimental evidence for facilitation of pair formation by bright color in weaverbirds. Condor 81:9193.

Darwin, C. 1871. The descent of man and selection in relation to sex. J. Murray, London.

Dennert, G. 1984. Retinoids and the immune system: immunostimulation by vitamin A. Pages 373-390 in M. B. Sporn, A. B. Roberts, and D. S. Goodman, eds. The retinoids. Academic Press, New York.

Endler, J. A. 1983. Natural and sexual selection on color patterns in poeciliid fishes. Environmental Biology of Fishes 9:173-190.

Felsenstein, J. 1985. Phylogenies and the comparative method. American Naturalist 125:1-15.

1988. Phylogenies and quantitative characters. Annual Review of Ecology and Systematics 19:445-471.

Folstad, I., and A. J. Karter. 1992. Parasites, bright males, and the immunocompetence handicap. American Naturalist 139:603-622.

Ford, N. L. 1983. Variation in male fidelity in monogamous birds. Current Ornithology 1:329356.

Fox, D. L. 1976. Animal biochromes and structural colors. University of California Press, Berkeley. 1979. Biochromy. University of California Press, Berkeley.

Fox, H. M., and G. Vevers. 1960. The nature of animal colors. Macmillan, New York.

Garland, T., P. H. Harvey, and A. R. Ives. 1992. Procedures for the analysis of comparative data using phylogenetically independent contrasts. Systematic Biology 41:18-32.

Garland, T., Jr., A. W. Dickerman, C. M. Janis, and J. A. Jones. 1993. Phylogenetic analysis of covariance by computer simulation. Systematic Biology 42:265-292.

Goodwin, T. W. 1952. The comparative biochemistry of the carotenoids. Chapman \& Hall, London.

Götmark, F. 1993. Conspicuous coloration in male birds is favored by predation in some species and disfavored in others. Proceedings of the Royal Society of London B, Biological Sciences 253:143-146.

Grafen, A. 1990. Biological signals as handicaps. Journal of Theoretical Biology 144:517-546.

Hamilton, W. D., and M. Zuk. 1982. Heritable true fitness and bright birds: a role for parasites? Science (Washington, D.C.) 218:384-386.

Harrison, C. J. O. 1985. Plumage, abnormal. Pages 472-474 in B. Campbell and E. Lack, eds. A dictionary of birds. Buteo, Vermillion, S.D.

Harvey, P. H., and M. D. Pagel. 1991. The comparative method in evolutionary biology. Oxford University Press, Oxford.

Hasson, O. 1990. The role of amplifiers in sexual selection: an integration of the amplifying and the Fisherian mechanisms. Evolutionary Ecology 4:277-289.

1991. Pursuit-deterrent signals: communication between prey and predator. Trends in Ecology \& Evolution 6:325-329.

Hill, G. E. 1990. Female house finches prefer colourful males: sexual selection for a condition dependent trait. Animal Behaviour 40:563-572.

1991. Plumage coloration is a sexually selected indicator of male quality. Nature (London) 350:337-339. 
1994a. House finches are what they eat: a reply to Hudon. Auk 111:221-225.

$1994 b$. Geographic variation in male ornamentation and female preferences in the house finch: a comparative test of models of sexual selection. Behavioral Ecology 5:64-73.

Hill, G. E., and R. Montgomerie. 1994. Plumage colour signals nutritional condition in the house finch. Proceedings of the Royal Society of London B, Biological Sciences 258:47-52.

Hill, G. E., R. Montgomerie, C. Y. Inouye, and J. Dale. 1994. Influence of dietary carotenoids on plasma and plumage colour in the house finch: intra- and intersexual variation. Functional Ecology 8:343-350.

Houde, A. E., and A. J. Torio. 1992. Effect of parasitic infection on male color pattern and female choice in guppies. Behavioral Ecology 3:346-351.

Hudon, J. 1994. Showiness, carotenoids, and captivity: a comment on Hill (1992). Auk 111:218221.

Hudon, J., and A. H. Brush. 1992. Identification of carotenoid pigments in birds. Methods in Enzymology 213:312-321.

Johnson, K., R. Dalton, and N. Burley. 1993. Preferences of female American goldfinches (Carduelis tristis) for natural and artificial male traits. Behavioral Ecology 4:138-143.

Johnson, S. G. 1991. Effects of predation, parasites, and phylogeny on the evolution of bright coloration in North American male passerines. Evolutionary Ecology 5:52-62.

Kodric-Brown, A. 1985. Female preference and sexual selection for male coloration in the guppy (Poecilia reticulata). Behavioral Ecology and Sociobiology 17:199-206.

1989. Dietary carotenoids and male mating success in the guppy: an environmental component to female choice. Behavioral Ecology and Sociobiology 25:393-401.

Kodric-Brown, A., and J. H. Brown. 1984. Truth in advertising: the kinds of traits favored by sexual selection. American Naturalist 124:309-323.

Krebs, J. R. 1979. Bird colours. Nature (London) 282:14-16.

Lack, D. 1954. The natural regulation of animal numbers. Clarendon, Oxford.

Leroi, A. M., M. R. Rose, and G. V. Lauder. 1994. What does the comparative method reveal about adaptation? American Naturalist 143:381-402.

Ligon, J. D., and P. W. Zwartjes. 1995. Ornate plumage of male red jungle fowl does not influence mate choice by females. Animal Behaviour 49:117-125.

Ligon, J. D., R. Thornhill, M. Zuk, and K. Johnson. 1990. Male-male competition, ornamentation and the role of testosterone in sexual selection in red jungle fowl. Animal Behaviour 40: 367-373.

Lyon, B. E., and R. D. Montgomerie. 1985. Conspicuous plumage of birds: sexual selection or unprofitable prey? Animal Behaviour 33:1038-1040.

Martins, E. P., and T. Garland. 1991. Phylogenetic analysis of the correlated evolution of continuous characters: a simulation study. Evolution 45:534-557.

Mather, J. P., and D. M. Phillips. 1986. Effects of retinoids on testicular cell function in vitro. Pages 17-28 in M. I. Sherman, ed. Retinoids and cell differentiation. CRC, Boca Raton, Fla.

Miles, D. B., and A. E. Dunham. 1993. Historical perspectives in ecology and evolutionary biology: the use of phylogenetic comparative analyses. Annual Review of Ecology and Systematics 24:587-619.

Milinski, M., and T. C. M. Bakker. 1990. Female sticklebacks use male coloration in mate choice and hence avoid parasitized males. Nature (London) 344:330-333.

Møller, A. P. 1986. Mating systems among European passerines: a review. Ibis 128:234-250.

- 1987a. Variation in badge size in male house sparrows Passer domesticus: evidence for status signalling. Animal Behaviour 35:1637-1644.

1987b. Social control of deception among status signalling house sparrows Passer domesticus. Behavioral Ecology and Sociobiology 20:307-311.

Møller, A. P., and T. R. Birkhead. 1994. The evolution of plumage brightness in birds is related to extrapair paternity. Evolution 48:1089-1100.

Møller, A. P., and A. Pomiankowski. 1993. Why have birds got multiple sexual ornaments? Behavioral Ecology and Sociobiology 32:167-176. 
Moon, R. C., and L. M. Itri. 1984. Retinoids and cancer. Pages 327-371 in M. B. Sporn, A. B. Roberts, and D. S. Goodman, eds. The retinoids. Academic Press, New York.

Moore, F. R., and M. V. McDonald. 1993. On the possibility that intercontinental landbird migrants copulate en route. Auk 110:157-160.

National Geographic Society. 1987. Field guide to the birds of North America. 2d ed. National Geographic Society, Washington, D.C.

Owens, I. P. F., and R. V. Short. 1995. Hormonal basis of sexual dimorphism in birds: implications for new theories of sexual selection. Trends in Ecology \& Evolution 10:44-47.

Partali, V., S. Liaaen-Jensen, T. Slagsvold, and J. T. Lifjeld. 1987. Carotenoids in food chain studies. II. The food chain of Parus spp. monitored by carotenoid analysis. Comparative Biochemistry and Physiology B, Comparative Biochemistry 87:885-888.

Peek, F. W. 1972. An experimental study of the territorial function of vocal and visual display in the male red-winged blackbird (Agelaius phoeniceus). Animal Behaviour 30:112-118.

Petrie, M. 1994. Improved growth and survival of offspring of peacocks with more elaborate trains. Nature (London) 371:598-599.

Pitt, G. A. J. 1971. Vitamin A. Pages 717-742 in O. Isler, ed. Carotenoids. Birkhäuser, Basel.

Purvis, A., and T. Garland, Jr. 1993. Polytomies in comparative analyses of continuous characters. Systematic Biology 42:569-575.

Pyle, P., S. N. G. Howell, R. P. Yunick, and D. F. DeSante. 1987. Identification guide to North American passerines. Slate Creek Press, Bolinas, Calif.

Roberts, A. B., and M. B. Sporn. 1984. Cellular biology and biochemistry of the retinoids. Pages 209-286 in M. B. Sporn, A. B. Roberts, and D. S. Goodman, eds. The retinoids. Academic Press, New York.

Rohlf, F. J., and R. R. Sokal. 1981. Statistical tables. W. H. Freeman, New York.

Røskaft, E., and S. Rohwer. 1987. An experimental study of the function of the red epaulettes and the black body colour of male red-winged blackbirds. Animal Behaviour 35:1070-1077.

Ruff, M. D., W. M. Reid, and K. Johnson. 1974. Lowered blood carotenoid levels in chickens infected with coccidia. Poultry Science 53:1801-1809.

Ryan, M. J., and A. Keddy-Hector. 1992. Directional patterns of female mate choice and the role of sensory biases. American Naturalist 139:S4-S35.

Ryan, P. G., C. L. Moloney, and J. Hudon. 1994. Color variation and hybridization among Nesopiza buntings on Inaccessible Island, Tristan da Cunha. Auk 111:314-327.

Selander, R. K. 1972. Sexual selection and dimorphism in birds. Pages 180-230 in B. Campbell, ed. Sexual selection and the descent of man, 1871-1971. Aldine, Chicago.

Sibley, C. G. 1957. The evolutionary and taxonomic significance of sexual dimorphism and hybridization in birds. Condor 59:166-191.

Sibley, C. G., and J. E. Ahlquist. 1990. Phylogeny and classification of birds: a study in molecular evolution. Yale University Press, New Haven, Conn.

Slagsvold, T., and J. T. Lifjeld. 1985. Variation in plumage colour of the great tit Parus major in relation to habitat, season and food. Journal of Zoology (London) 206:321-328.

Smith, D. G. 1972. The role of the epaulets in the red-winged blackbird (Agelaius phoeniceus) social system. Behaviour 41:251-268.

Smith, S. M. 1977. Coral-snake pattern recognition and stimulus generalization by naive great kiskadees (Aves: Tyrannidae). Nature (London) 265:535-536.

Trail, P. W. 1990. Why should lek-breeders be monomorphic? Evolution 44:1837-1852.

Underwood, B. A. 1984. Vitamin A in animal and human nutrition. Pages 281-392 in M. B. Sporn, A. B. Roberts, and D. S. Goodman, eds. The retinoids. Academic Press, New York.

Verner, J., and M. F. Willson. 1969. Mating systems, sexual dimorphism, and the role of male North American passerine birds in the nesting cycle. Ornithological Monographs 9:1-76.

Witschi, E. 1961. Sex and secondary sexual characters. Pages 115-168 in A. J. Marshall, ed. Biology and comparative physiology of birds. Academic Press, New York.

Zahavi, A. 1975. Mate selection: a selection for a handicap. Journal of Theoretical Biology 53:205214. 
1991. On the definition of sexual selection, Fisher's model, and the evolution of waste and of signals in general. Animal Behaviour 42:501-503.

Zuk, M. 1992. The role of parasites in sexual selection: current evidence and future directions. Advances in the Study of Behavior 21:39-68.

Zuk, M., R. Thornhill, J. D. Ligon, and K. Johnson. 1990a. Parasites and mate choice in red jungle fowl. American Zoologist 30:235-244.

Zuk, M., R. Thornhill, J. D. Ligon, K. Johnson, S. Austad, S. H. Ligon, N. W. Thornhill, and C. Costin. 1990b. The role of male ornaments and courtship behavior in female choice of red jungle fowl. American Naturalist 136:459-473.

Associate Editor: Theodore Garland, Jr. 